\title{
The Syntax of Wh-Questions in Gichuka
}

\author{
Peter Kinyua Muriungi', Miriam Kathomi Mutegi², Mary Karuri ${ }^{1}$ \\ ${ }^{1}$ Chuka University, Chuka, Kenya \\ ${ }^{2}$ Ndagani Secondary School, Chuka, Kenya \\ Email: muriungip@yahoo.com, kathomimiriam@yahoo.com, nyanjugu2001@yahoo.com
}

Received 7 June 2013; revised 9 July 2013; accepted 18 July 2013

Copyright (C) 2014 by authors and Scientific Research Publishing Inc.

This work is licensed under the Creative Commons Attribution International License (CC BY). http://creativecommons.org/licenses/by/4.0/

c) (i) Open Access

\section{Abstract}

This study investigated wh-question formation in Gichuka, an SVO Bantu language spoken in Kenya. The study established that Gichuka forms wh-question using the four strategies, namely: wh-in situ, full wh-movement, partial wh-movement, and intermediate strategy. In wh-in situ, the $w h$-phrase does not move. In full wh-movement, the $w h$-phrase moves to the beginning of the sentence. In partial wh-movement, the wh-phrase moves to an intermediate Spec, CP. In the intermediate strategy, the wh-phrase moves to an intermediate Spec, CP, or a Spec of the matrix CP, followed by movement of the subject to position above $\mathrm{CP}$, a Topic position. These findings are similar to those of Muriungi (2003) who established that Kitharaka, a related Bantu language forms questions using the four strategies. As in Muriungi (2003), the study established that subjects cannot be questioned in situ.

\section{Keywords}

Wh-in Situ; Full Wh-Movement; Partial Wh-Movement; Intermediate Wh-Movement; Gichuka; Bantu

\section{Background to the Study}

According to Fromkin, Robert, Neil, \& Harry (2001), one of the linguistic universals is that all languages have a way of asking questions. Different languages have various ways of forming wh-questions which include full wh-movement, partial wh-movement and wh-in situ.

In English, the wh-word moves from the underlying object position to the beginning of the question as shown in (1) below:

1. (a) You bought a bicycle (object).

(b) *You bought what?

(c) What did you buy? (Full wh-movement) (Anisa, 2009; Kristin, 2000; Puskas, 1997; Sabel \& Zeller, 2004; 
Norberto, 2004).

1(b) is ungrammatical because the $w h$-word has remained in the position of the object that is the position after the verb. This is not allowed in English. However, (1b) is grammatical as an echo question.

To formulate questions on adjuncts in English, the $w h$-word moves from the underlying position of adjuncts, the position after the verb, to the beginning of the question as shown below:

2. (a) He writes quickly (adjunct)

(b) *He writes how?

(c) How does he write?

3. (a) He writes everyday (adjunct)

(b) *He writes when?

(c) When does he write?

4. (a) He writes for fun? (adjunct)

(b) *He writes why?

(c) Why does he write? (full wh-movement).

5. (a) He writes on a paper (adjunct)

(b) *He writes where?

(c) Where does he write? (full wh-movement). (full $w h$-movement in English is described and analyzed in Chomsky's seminar paper on wh-movement) (Chomsky, 1977).

Typically, English only allows full $w h$-movement. This accounts for the ungrammaticality of the examples in (1b), (2b), (3b), (4b), and (5b).

In some languages, the $w h$-word can remain in situ, that is, it is not moved at all. It remains in the position where we find the corresponding non-wh-phrase. This is evident in Kiswahili and Kikuyu.

When forming object $w h$-questions in Kiswahili, the $w h$-word can remain in the canonical position of the object. It appears after the verb, the position where we also find the object. This is wh-in situ.

6. (a) Mtoto alipiga mbwa (object)

Child beat dog

"Child beat the dog"

(b) Mtoto alipiga nini? (wh-in situ).

Child beat what?

"What did the child beat"

When forming adjunct $w h$-questions in Kiswahili, the $w h$-word can remain in the canonical position of the adjunct as shown in (7):

7. (a) Mtoto alienda shuleni (statement with a locative adjunct)

Child went school

"The child went to school"

(b) Mtoto alienda wapi? (wh-in situ)

Child went where?

"Where did the child go?"

8. (a) Mtoto alienda asubuhi (statement with a time adjunct)

Child went morning

"The child went in the morning"

(b) Mtoto alienda lini?

Child went when?

"When did the child go"

9. (a) Mtoto alienda shuleni kwagari (statement with a means adjunct).

Child went school by bus.

"The child went to school by bus."

(b) Mtoto alienda shuleni vipi? (wh-in situ).

Child went school how?

"How did the child go to school?"

10. (a) Mtoto alienda shuleni kusoma (statement with a reason adjunct).

Child went school to read

"The child went school to read." 
(b) Mtoto alienda shuleni kwa nini? (wh-in situ).

Child went school why?

"Why did the child go to school?"

In addition to Kiswahili's allowing wh-in situ, it also allows full wh-movement. This is where the $w h$-word moves from its canonical position to the beginning of the sentence. The moved $w h$-phrases in Kiswahili typically contain the particle $n i$ in Bantu, which is referred to as the focus marker as shown in (11b) and (12b):

11.(a) Mtoto alienda shuleni (adjunct).

Child went school

"The child went to school"

(b) Ni wapimtoto alienda? (adjunct full wh-question)

Where child went

"Where did the child go?"

12. (a) Mtoto alipiga mbwa (object)

Child beat dog

"The child beat the dog."

(b) Ni nini mtoto alipiga? (Object full wh-question).

What child beat

"What did the child beat?"

In Kikuyu, wh-in situ is allowed. The wh-word remains in the underlying position of objects, adjuncts and subjects. According to Clements and Ford (1979) Kikuyu wh-phrases stay in their base position in the overt syntax as shown in (13) and (14):

13.(a) Kamau onire ngui (object)

Kamau saw dog

"Kamau saw a dog"

(b) Kamau onire ndui? (Object wh-in situ question).

Kamau saw what.

"What did Kamau see?"

14. (a) Wangari athire cukuru (adjunct)

Wangari went school.

"Wangari went to school"

(b) Wangari athire ku? (adjunct wh-in situ question)

Wangari went where?

"Where did Wangari go?"

According to Bergvall (1987), Kikuyu also allows partial $w h$-movement where the underlying $w h$-word moves from its canonical position to some intermediate position of the sentence as shown in (15).

15. Maria etikitie nindui John agurire?

Maria believes what John bought?

"What does Maria believe John bought?"

According to Clements (1984), Kikuyu also allows full $w h$-movement where the $w h$-word moves to the front of the sentence as shown in (16):

16. Nikũ Ngugi augire atiKamau nĩonire Kaanake?

Where Ngugi said that Kamau saw Kaanake?

"Where did Ngugi say that Kamau saw Kaanake?"

Typically Kikuyu uses three strategies in forming wh-questions that is, full wh-movement, wh-in situ and partial wh-movement. Moved wh-phrases bear the focus marker morpheme ni. wh-phrases, that are in situ not bearing $n i$. The particle $n i$ is therefore diagnostic of movement in Kikuyu and Bantu languages in general German allows partial $w h$-movement where the $w h$-word moves to the middle of the sentence. According to McDaniel (1986) the scope of $w h$-phrase moved to the middle of the sentence is marked by a $w h$-expletive which appears in initial position of the sentence, (17):

17. Was glaubst du welchen Mantel Jakob heute angezogen hat?

What do you think which coat Jacob put on today?

In example (20a) "was" in German is "what" in English. It is a wh-expletive, that is, it carries no meaning; it is only a requirement when constructing wh-questions in German for reasons of scope. The contentive wh- 
phrase "which coat has been partially moved."

\section{Statement of the Problem}

It is a linguistic universal that all languages have strategies of questioning. These strategies include full whmovement, wh-in situ and partial movement. While it is documented that English only allows full $w h$-movement; German allows partial wh-movement and full-wh movement; Kikuyu, Dholuo, Kitharaka, Zulu and Babine Witsuwiten allow full-wh movement, partial wh movement and wh in situ, the strategies of forming $w h$-questions in Gichuka are not known and have not been documented. Therefore, the study investigated and documented these strategies and located these strategies in the general cross-linguistic wh-question formation strategies.

\section{Objectives}

i) To discuss the strategies of formulating object, subject and adjunct wh-questions in Gichuka.

ii) To describe the structural representations of objects, subjects and adjunct $w h$-questions in Gichuka.

\section{Results and Discussion}

The presentation in this section is guided by the two research objectives.

The first objective was to establish and discuss the strategies of formulating object, subject and adjunct wh questions in Gichuka. From the literature review, it was stated that cross linguistically, there are three strategies of forming $w h$ questions. They include full $w h$ movement/ex situ, wh in situ and partial $w h$ movement. In full wh movement the $w h$ phrase moves to the specifier of CP of the matrix clause while in partial wh movement, the $w h$ phrase moves to the specifier of $\mathrm{CP}$ of an embedded clause. Wh in situ does not involve any movement.

\subsection{Objects}

Objects in English are questioned by two whphrases; what and who. The equivalents of these in Gichuka are 'mbi' and 'uu' Consider the affirmative sentence in 18(a):

18(a) kairitu karugire irio

Girl cooked food

$\mathrm{S} \mathrm{V} O$

"The girl cooked food"

To question the object "irio", the wh phrase can move to the initial position of the sentence. This strategy is full wh movement/ex situ as in 18(b).

18(b) Nimbi kairitu karugire? (full wh movement)

\section{f-what girl cooked}

"What did the girl cook?"

As evident in 18(b), the focus marker "ni" is added to wh phrase to form "nimbi". However if the focus marker is not added the sentence becomes ungrammatical as shown in 18(c):

*18(c) Mbi kairitu karugire?

What girl cooked

The object "irio" can also be questioned by moving the wh phrase to the middle of the sentence as shown in $18(\mathrm{~d})$.

18(d) Kairitu nimbi karugire? (intermediate $w$ hovement)

Girl f-what cooked

"What did the girl cook?"

In 18(d), The wh phrase appears in the intermediate position. This is the intermediate strategy. In this strategy, the $w h$ phrase moves to a position immediately after the subject of the sentence. The focus marker "ni" is added just as in the case of full $\boldsymbol{w h}$ movement. However, if the focus marker is not added to the wh phrase after the movement, the question becomes ungrammatical as shown 18(e).

*18(e) Kairitu mbi karugire?

Girl what cooked

The $w h$ phrase can also remain in the canonical position of the object. This means that the $w h$ phrase does not move at all. 
18(f) Kairitu karugire mbi? (wh in situ)

Girl cooked what

"What did the girl cook?"

As shown in (4f), the wh phrase remains in the position of the object but no focus marker is added. However if the focus marker added the sentence becomes ungrammatical as in $18(\mathrm{~g})$ :

* 18 (g) Kairitu karugire nimbi?

Girl cooked f-what

Full wh movement, intermediate strategy and wh in situ are also possible in complex sentences. Consider the complex affirmative sentence in 19(a).

19(a) John etikitie mwende augire kairitu karugire irio. (complex sentence)

John believe Mwende said girl cooked food

"John believes Mwende said the girl cooked food"

To question the object "irio", the wh phrase can move to the initial position of the sentence. A focus marker "ni" is added.

19(b) Nimbi John etikitie Mwende augire kairitu nikarugire?

f-what John believe Mwende said girl cooked

'What does John believe Mwende said the girl cooked food?'

If the focus marker "ni" is not added, an ungrammatical construction is made as shown in 19(c).

*19(c) Mbi John etikitie Mwende augire kairitu nikarugire?

What John believe Mwende said girl cooked

The object "irio" can also be questioned by moving the wh phrase to the specifier of CP of the second embedded clause.

This is partial wh movement. Consider 19(d).

(19d) John etikitie nimbi Mwende augire kairitu nikarugire (PM)

John believe f-what Mwende said girl cooked

"What does John believe Mwende said the girl cooked?"

In 19(d), the movement of the $w h$ phrase to the second embedded clause. It's evident that the focus marker "ni" is added to it.

The wh phrase can also move to the specifier of $\mathrm{CP}$ of the most embedded clause having the focus marker "ni" as shown in 19(e).

19(e) John etikitie Mwende augire nimbi kairitu karugire? (PM)

John believe Mwende said f-what girl cooked

"What does John believe Mwende said the girl cooked?"

If the $w h$ phrase moves to a position after any of the embedded clauses, a focus marker must be added to it. However, if it is not added, the question becomes ungrammatical as shown in $19(\mathrm{f})$ and $19(\mathrm{~g})$.

*19(f) John etikitie mbi Mwende augire kairitu nikarugire?

John believes what Mwende said girl cooked

*19(g) John etikitie Mwende augire mbi kairitu karugire?

John believes Mwende said what girl cooked

It is also possible to move the $w h$ phrase to a position that immediately follows the subject.This is the intermediate strategy in complex questions.

19(h) John nimbi etikitie Mwende augire kairitu nikarugire? (IM)

John f-what believe Mwende said girl cooked

"What does John believe Mwende said the girl cooked food"

19(i) John etikitie Mwende nimbi augire kairitu nikarugire? (IM)

John believe Mwende f-what said girl cooked

"What does John believe Mwende said the girl cooked?"

In 19(h) and 19(i), the focus marker is added to the wh phrase. Malformed questions are formed if the focus marker is not added shown in 19(j) and 19(k).

*19(j) John mbi etikitie Mwende augire kairitu nikarugire? (IM)

John what believes Mwende said girl cooked

*19(k) John etikitie Mwende mbi augire kairitu nikarugire? (IM)

"John believe Mwende what said girl cooked." 
Wh in situ is also possible in a complex sentence. The wh phrase remains in the position where we find the object 'irio'.

19 (1) John etikitie Mwende augire kairitu karugire mbi? (wh in situ)

John believes Mwende said girl 1 cooked what?

'What does John believe Mwende said the girl cooked?'

The focus marker is not present in 19(1) as the wh phrase has not moved. However, if we add a focus marker 'ni' to the $w h$ phrase the sentence is ungrammatical. Consider 19(m).

*19(m) John etikitie Mwende augire kairitu karugire nimbi?

John believes Mwende said girl cooked f-what?

The other object wh-phrase which is "uu" is seen to behave the same as "mbi" in different constructions.

There is the addition of a focus marker whenever the $w h$ phrase moves. However, in the case of the wh phrase "uu"(who) the focus marker "ni" is added even if in most cases "i i" is usually omitted and becomes optional. Therefore, the $w h$ phrase becomes "n(i)uu" or "nuu". Consider 19(n) and 19(o).

19(n) Nuu murimi aringire? (wh full-movement)

F-who Murimi beat?

"Who did Murimi beat?"

19(o) Murimi nuu aringire? (intermediate $w h$ movement)

Murimi f-who aringire?

"Who did Murimi beat?"

If no focus marker is added, the wh questions becomes ungrammatical as shown in 19(p) and 19(q):

*19(p) Uu Murimi aringire? (FM)

Who Murimi beat?

*19(q) Murimi uu aringire? (IM)

Murimi who beat?

"Who did Murimi beat?"

In case the $w h$ phrase does not move at all, then no focus marker is needed.

19(r) Murimi aringire uu (wh in situ)

Murimi beat who?

"Who did Murimi beat?"

Therefore it is ungrammatical to add a focus marker if the $w h$ phrase has not moved.

*19(s) Murimi aringire nuu? (wh in situ)

Murimi beat f-who

"Who did Murimi beat?"

From the data in (18) and (19) above, the following observations can be made.

i) There are four strategies involved in forming object $w h$ questions in Gichuka. These are, wh full movement, partial wh movement, intermediate wh-movement and wh in situ.

ii) Whenever the object $w h$-phrases "mbi" and "uu" move, the focus marker 'ni' must be added to them.

iii) If the $w h$ phrase remains in situ, no focus markers are needed.

\subsection{Subjects}

Subjects wh questions are formed by wh phrases "what" and "who" which are "mbi" and "uu" in Gichuka respectively.

Consider the sentence in 20(a). The subject of the sentence is 'Kairitu'-girl.

20(a) Kairitu karugire irio.

Girl cooked food.

$\mathrm{S} \mathrm{V} \mathrm{O}$

"The girl cooked food."

To question the subject "girl", full wh movement is possible, as in 20(b).

20(b) Nuu arugire irio? (full wh movement)

f-who cooked food.

'Who cooked the food?'

20(b), Shows that it is possible that the wh phrase "uu" has moved. This is because of the addition of a focus 
marker ' $\mathbf{n i}$ '. This movement is evident as the sentence is ungrammatical if a focus marker is not added, as shown in $20(\mathrm{c})$.

*20(c) Uu arugire irio?

Who cooked food.

Wh in situ is not possible when constructing subject wh questions. This explains the ungrammaticality of 20(f):

*20(f) Uu arugire irio? (wh in situ)

who cooked food

"Who cooked the food?"

In a complex sentence the subject $w h$ phrase can move to the beginning of the sentenceas in 21(a):

21(a) Nuu John etikitie Mwende augire niarugire irio? (full wh movement)

F-who John believes Mwende, said cooked food?

"Who does John believes Mwende said cooked food?"

The focus marker " $n$ "is added however if it is left out the sentence becomes ungrammatical.

*21(b) Uu John etiikitie Mwende augire niarugire irio?

Who John believe Mwende said cooked food?

Partial wh movement is also evident in a subject wh question as shown in 21(c).

21(c) John etikitienuu mwende augire niarugire irio? (partial wh movement)

John believes f-who Mwende said cooked food.

"Who does John believe Mwende said cooked the food?"

In 21(c), the wh phrase moves to a position after the second embedded clause.

The focus marker "n" is added to the subject $w h$ phrase when it moves. If the focus marker is left out, the sentence becomes ungrammatical as in 21 (d).

*21(d) John etikitie uu Mwende augire niarugire irio?

John believes who Mwende said cooked food?

The subject $w h$ phrase can also move to a position that immediately follows the subject as in 21(e) and 21(f)

21(e) Johnnuuetikitie Mwende augire niarugire irio? (intermediate wh movement)

John f-who believe Mwende said cooked food.

"Who does John believe Mwende said cooked food?"

21(f) John etikitie Mwende nuu augire niarugire irio? (intermediate wh movement)

John believe Mwende f-who said cooked food.

"Who does John believe Mwende said cooked food?"

In both movements, the focus marker " $\mathbf{n}$ " is added to the wh phrase. However if it is left out, again the sentence becomes ungrammatical as in 21(i) and 21(j).

*21(i) John etikitie Mwende uu augire niarugire irio? John believe mwende who said cooked food?

*21(j) John uu etikitie Mwende augire niarugire irio? John who believe mwende said cooked food.

Wh in situ is not possible in subject wh questions.

*21(k) John etikitie Mwende augire uu arugire irio? (wh in situ) John believe Mwende said who cooked food?

The wh "phrase mbi" (what) has the same distribution as "uu"(who). When moved, a focus marker is added to the wh phrase. We add focus markers "ni" to "mbi" and "n" to "uu". In both wh phrases, wh in situ is imposible when forming subject $w h$-questions.

From the data in (20) and (21) above the following observations are made.

(i) In order to form a subject $w h$ question, movement is compulsory. Therefore, full $w h$ movement, partial $w h$ movement and intermediate $w h$ movement are involved.

(ii) It is impossible to form a subject $w h$ question when the $w h$ phrase is in situ.

(iii) Focus markers are added to the $w h$ phrases. "ni" is added to the subject $w h$ phrase "mbi" while "n" is added to the subject $w h$ phrase "uu".

Table 1 is showing the strategies for objects and subjects.

From Table 1, the object wh questions allow all the strategies of formulating wh question while the subjects allow full, partial and intermediate $w h$ movement.

The subjects do not allow wh in situ. 
Table 1. Strategies of $w h$ question formation for objects and subjects.

\begin{tabular}{ccccc}
\hline & \multicolumn{3}{c}{ Strategies } \\
Objects & Full $\sqrt{ }$ & Partial $\sqrt{ }$ & Intermediate $\sqrt{ }$ & Wh in situ $\sqrt{ }$ \\
Subjects & $\sqrt{ }$ & $\sqrt{ }$ & $\sqrt{ }$ & $\mathrm{X}$ \\
\hline
\end{tabular}

\subsection{Adjuncts}

The adjuncts wh questions answer the questions when, where, how and why. We begin by investigating the strategies involved in forming questions using the adjunct 'when'.

\subsubsection{When}

Consider the sentence 22(a). The adjuncts is "muramuko".

22(a) kairitu karugire irio muramuko.

Girl cooked food Monday.

"The girl cooked the food on Monday.

To question the adjunct"muramuko"the wh phrase "ri" can move to the initial position of the sentence as shown in 22(b):

22(b) Niri kairitu karugire irio? (full wh-movement)

F-when girl cooked food?

"When did the girl cook food?

The $w h$ phrase "ri" is added a focus marker "ni" when it moves .If the focus marker is not added the sentence is ungrammatical.

*22(c) Ri kairitu karugire irio?

When girl cooked food?

The intermediate $w h$ movement is also evident in this adjunct.

22(d) Kairitu niri karugire irio? (intermediate wh movement)

Girl f-when cooked food

"When did the girl cook food?"

Just as in the case of full wh movement a focus marker is added to the wh phrase. If the focus marker is left out the sentence becomes ungrammatical.

*22(e) Kairitu ri karugire irio?

Girl when cooked food.

Wh in situ is possible with adjunct $w h$ phrase "ri".

22(f) Kairitu karugire irio ri? (wh in situ)

Girl cooked food when?

"When did the girl cook food?"

As evident in 22(f), the wh phrase does not contain a focus marker. This is because it has not moved at all. It is ungrammatical to add a focus marker "ni" if the $w$ h phrase has not moved as in $22(\mathrm{~g})$ :

*22(g) Kairitu karugire irio niri?

Girl cooked food f-when?

Consider a complex sentence such as $23(\mathrm{a})$ :

23(a) John etikitie Mwende augire kairitu karugire irio muramuko.

John believe Mwende said girl cooked food Monday.

"John believes Mwende said the girl coked the food on Monday."

To question "muramuko" full $w h$ movement can be allowed as shown in 23(b)

23(b) Niri John etikitie Mwende augire kairitu nikarugire irio? (full wh movement)

F-when John believe Mwende said girl cooked food.

"When does John believe Mwende said the girl cooked food?"

A focus marker "ni" is added to the $w$ phrase. However if it is left out, the sentence becomes ungrammatical as in 23(c).

*23(c) Ri John etikitie Mwende augire kairitu nikarugire irio.

When John believe Mwende said girl cooked food. 
Partial wh movement is also possible as in 23(d) and 23(e)

23(d) John etikitie niri Mwende augire kairitu karugire irio? (partial wh movement) John believe f-when Mwende said girl cooked food "When does John believe the girl cooked food?"

23(e) John etikitie Mwende augire niri kairitu karugire irio? (partial wh movement) John believe Mwende said f-when girl cooked food.

"When does John believe the girl cooked food?"

In 23(d) above, the wh phrase moves to the position after the most embedded clause while in 23(e) the wh phrase moves to the position after the second embedded clause. The focus marker "ni" is added to the wh-phrase when the wh moves. If no focus marker is added after the movement, the sentence is ungrammatical as in 23(f) and $23(\mathrm{~g})$.

*23(f) John etikitie ri Mwende augire kairitu karugire irio? John believe when Mwende said girl cooked food?

*23(g) John etikitie Mwende augire ri kairitu karugire irio? John believes Mwende said when girl cooked food?

The adjunct "when"also allows intermediate $\boldsymbol{w h}$ movement where the $w h$ phrase moves to the position after the subject in a complex sentense as in 23(h) and 23(i):

23 (h) John niri etikitie Mwende augire kairitu nikarugire irio? (intermediate wh movement)

John f-when believe Mwende said girl cooked food?

"When does John believe Mwende said the girl cooked food?"

23 (i) John etikitie Mwende niri augire kairitu nikarugire irio? (IM)

John believes Mwende f-when said girl cooked food?

"When does John believe Mwende said the girl cooked food?"

If the focus marker is not added in the sentences $23(\mathrm{~h})$ and 23(i), they become ungrammatical as in $23(\mathrm{k})$ and 23(1) respectively:

*23(k) John ri etikitie Mwende augire kairitu nikarugire irio? John when believes Mwende said girl cooked food.

*23(1) John etikitie Mwende ri augire kairitu nikarugire irio? John believes Mwende when said girl cooked food.

Its also possible to question the adjunct "kairitu" using wh in situ as in 23(m).

23(m) John etikitie Mwende augire kairitu karugire irio ri? (wh in situ) John believes Mwende said girl cooked food when?

"When does John believe Mwende said the girl cooked food?"

When the wh phrase does not move, no focus marker is added. If it is added the sentence is ungrammatical as in $23(\mathrm{n})$.

*23(n) John etikitie Mwende augire kairitu karugire irio niri?

John believe Mwende said girl cooked food f-when

\subsubsection{Where}

Consider sentence 24(a). The adjunct is "nchikoni".

24(a) Kairitu karugire irio nchikoni.

Girl cooked food kitchen.

"The girl cooked the food in the kitchen."

To question the adjunct "nchikoni", full wh mocement is possible as in 24(b):

24(b) Niku kairitu karugire irio? (full wh movement)

F-where girl cooked food.

"Where did the girl cook food?"

The $w h$ phrase is added a focus marker "ni".

If not added the sentence becomes ungrammatical as in 24(c).

*24(c) Ku kairitu karugire irio?

Where girl cooked food?

It is also possible to ask about the adjunct "nchikoni" using intermediate wh movement as shown in 24(d):

24(d) Kairitu niku karugire irio? (intermediate $w h$ movement) 
Girl f-where cooked food?

"Where did the girl cook food?"

Just as in full wh movement in 24(b) above, the focus marker "ni" must be added to the wh phrase whenever it moves. The sentence is ungrammatical without the focus marker "ni". Consider 24(e):

*24(e) Kairitu ku karugire irio?

Girl where cooked food?

Wh in situ is also possible in the above sentence. The wh phrase does not move, therefore no focus marker is added as shown in 24(f).

24(f) Kairitu karugire irio ku? (wh in situ)

Girl cooked food where?

"Where did the girl cook food?"

If the focus marker is is added, the sentence then becomes ungrammatical.

*24(g) Kairitu karugire irio niku?

Girl cooked food f-where?

In a complex sentence such as $25(\mathrm{a})$, the same rules are seen to apply.

Consider the sentence 25(a). The adjunct is "nchikoni".

25 (a) John etikitie Mwende augire kairitu karugire irio nchikoni. (complex sentence)

John believe Mwende said girl cooked food kitchen.

"John believes Mwende said the girl cooked food in the kitchen".

To question the adjunct "nchikoni" full wh movement is possible as in $25(\mathrm{~b})$.

25(b) Niku John etikitie Mwende augire kairitu nikarugire irio? (full wh movement)

F-where John believeMwende said girl cooked food.

"Where does John believe Mwende said the girl cooked food?"

The focus marker "ni" is added to the wh phrase whenever it moves. If it"s left out, the sentence is ungrammatical as in 25(c).

*25(c) Ku John etikiitie Mwende augire kairitu nikarugire irio?

Where John believe Mwende said girl cooked food

Partial whmovement is also possible when questioning the above adjunct. Always the focus marker is added to the $w h$ phrase whenever it moves as in 25(d) and 25(e):

25(d) John etikitie niku Mwende augire kairitu karugire irio? (partial wh movement) John believe f-where Mwende said girl cooked food?

"where does John believe Mwende said the girl coked food?"

25 (e) John etikitie Mwende augire niku kairitu karugire irio? (partial wh movement) John believe Mwende said f-where girl cooked food?

The $w h$ phrase moves to the position after the second embedded clause as in $25(\mathrm{~d})$ and to the most embedded clause as in 25(e):

Intermediate $w h$ movement is also possible (see 25(f) and 25(g)).

25(f) John niku etikitie Mwende augire kairitu nikarugire irio? (IM)

John f-where believe Mwende said girl cooked food

"Where does John believe Mwende said the girl cooked food?"

25(g) John etikitie Mwende niku augire kairitu nikarugire irio? (IM)

John believe Mwende f-where said girl cooked food.

"Where does John believe Mwende said the girl cooked food?"

Just as in full wh movement and partial wh movement the focus marker must be added to the wh phrase whenever it moves. Otherwise ungrammatical constructions result if the focus marker is not added, as in 25(h) and 25(i).

*25(h) John ku etikitie Mwende augire kairitu nikarugire irio? (IM)

John where believe Mwende said girl cooked food.

*25(I) John etikitie ku Mwende augire kairitu nikarugire irio? (PM)

John believes where Mwende said girl cooked food?

Wh in situ is also possible when questioningadjuncts. However a focus marker is not added to the wh phrase since no movement is evident as in $25(\mathrm{j})$.

25(j) John etikitie Mwende augirekairitu karugire irioku? (wh in situ) 
John believe Mwende said girl cooked food where

If the focus marker is added, the sentence becomes ungrammatical as in $25(\mathrm{k})$.

*25(k) John etikitie Mwende augire kairitu karugire irio niku? (wh in situ)

John believe Mwende said girl cooked food f-where.

\subsubsection{How}

Consider sentence 26(a). "Kabora" is the adjunct.

26(a) Kairitu karugire irio kabora.

Girl cooked food slowly

"The girl cooked food slowly"

To question the adjunct "kabora" full wh movement is possible as shown in 26(b):

26(b) Natia kairitu karugire irio? (full wh movement)

F-how girl cooked food

"How did the girl cook food?"

The $w h$ phrase must be added a focus marker "ni" whenever it moves. This explains the ungrammaticality of 26(c):

*26(c) Atia kairitu karugire irio? (full wh movement)

How girl cooked food

Intermediate $w h$ movement is also possible. There is a focus marker that is added to the $w h$ phrase see 26(d):

26(d) Kairitu natia karugire irio? (intermediate wh movement)

Girl f-how cooked food.

"How did the girl cook food?"

It is ungrammatical to have the above statements without a focus marker "ni" as in 26(e)

*26(e) Kairitu atia karugire irio?

Girl how cooked food.

Wh in situ can also be used to question the adjunct above as in 26(f):

26(f) Kairitu karugire irio atia? (wh in situ)

Girl cooked food how.

"How did the girl cook food?"

It"s ungrammatical to add a focus marker "ni" to the wh phrase if no movement is evident as shown in $26(\mathrm{~g})$.

*26(g) Kairitu karugire irio niatia? (wh in situ)

Girl cooked food f-how

The same distribution is evident in a complex sentence as in 27(a).

27(a) John etikitie mwende augire kairitu karugire irio kabora (complex sentence)

John believe Mwende said girl cooked food slowly.

"John believes Mwende said the girl cooked food slowly."

The adjunct "kabora" can be questioned using full wh movement as in 27(b).

27(b) Natia John etikitie Mwende augire kairitu nikarugire irio? (full wh movement)

F-how John believe Mwende said girl cooked food

"How does John believe Mwende said the girl cooked food?"

It"s ungrammatical to construct the above sentence without the focus marker "ni" as in 27(c)

*27(c) Atia John etikitie Mwende augire kairitu nikarugire irio? (full wh movement)

How John believes Mwende said girl cooked food.

Partial wh movement is also possible as the $w h$ phrase can move to a position after the most embedded clause and the second embedded clause as shown in 27(d) and 27(e) respectively.

27(d) John etikiitie niatia Mwende augire kairitu nikarugire irio? (partial wh movement)

John believe f-how Mwende said girl cooked food.

"How does John believe mwende said the girl cooked the food?"

27(e) John etikitie Mwende augire niatia kairitu karugire irio? (partial wh movement)

John believe Mwende said f-how girl cooked food.

"How does John believe Mwende said the girl cooked the food?"

The same rule applies in intermediate $w h$ movement. The focus marker must be added to the $w h$ phrase as in $27(\mathrm{f})$ and $27(\mathrm{~g})$ : 
27(f) John natia etikitie Mwende augire kairitu nikarugire irio? (intermediate wh movement)

John f-how believe Mwende said girl cooked food.

"How does John believe Mwende said the girl cooked food?"

27 (g) John etikitie mwende niatia augire kairitu nikarugire irio? (intermediate wh movement)

John believe Mwende f-how said girl cooked food .

"How does John believe Mwende said the girl cooked food?"

However if the focus marker in 27(d), 27(e), (13f) and 27(g) is not added ungrammatical construction are made. Consider 27(h) and 27(i).

*27 (h) John etikitie atia Mwende augire kairitu nikarugire irio? (partial wh movement) John believe how Mwende said girl cooked food

*27 (i) John atia etikitie Mwende augire kairitu nikarugire irio (intermediate wh movement) John how believe Mwende said girl cooked food.

Wh in situ is also possible, as in 27(j).

27(j) John etikitie Mwende augire kairitu karugire irio atia? (wh in situ)

John believe Mwende said girl cooked food how

"How does John believe Mwende said the girl cooked food?"

However the focus marker "ni" is not added when the movement is evident .If it"s added then ungrammatical construction is made, as in $27(\mathrm{k})$.

*27(k) John etikitie Mwende augire kairitu karugire irio niatia? (wh in situ)

John believe Mwende said girl cooked food f-how.

\subsubsection{Why}

Consider the sentence 28(a). The adjunct in the sentence is "karia".

28(a) Kairitu karugire irio karia

Girl cooked food eat

"Why did the girl cook food?"

To question "karia", full wh movement is possible as shown in 28(b).

28(b) Niki kairitu karugire irio? (full $w h$ movement)

Why girl cooked food

"Why did the girl cook food?"

The wh phrase "niki"is used for "why". It has remained in its original form even after the movement.

Consider 28(c).

28(c) Kairitu niki karugire irio? (intermediate $w h$ movement)

Girl why cooked food

"Why did the girl cook food?"

The above sentence demonstrates intermediate wh movement in which the original form of the word "why" which is "niki" does not change.

It"s also possible to question the adjunct using wh in situ as in 28(d).

28(d) Kairitu karugire irio niki? (wh in situ)

Girl cooked food why.

Interestingly, the $w h$ phrase does not change its form in any of the positions. This is a distinctive feature of the adjunct "why" in Gichuka. This is because in questioning all other adjuncts the focus marker "ni" is added to the form of the wh phrase.

Consider a complex sentence in 29 (a).

29 (a) John etikitie Mwende augire kairitu karugire irio karia (complex sentence) John believes Mwende said girl cooked food to eat.

"John believes Mwende said the girl cooked food to eat".

To question "karia" full wh movement is possible as in 29 (b).

29(b) Niki John etikitie Mwende augire kairitu nikarugire irio? (full wh movement)

Why John believe Mwende said girl cooked food.

"Why does John believe Mwende said the girl cooked food?"

It's also possible to question "irio" using partial wh movement. This will involve the wh phrase moving to the position after the most embedded clause as in 29(c) and 29(d) respectively. 
29 (c) John etikitie niki Mwende augire kairitu nikarugire irio? ( partial wh movement) John believe why Mwende said girl cooked food.

"Why does John believe Mwende said the girl cooked food?"

29 (d) John etikitie mwende augire niki kairitu karugire irio? (partial wh movement)

John believe Mwende said why girl cooked food.

"Why does john believe Mwende said the girl cooked food?"

The same rule applies in partial wh movement, that is, the original form of the wh phrase does not change at all.

Consider the sentence 29(e).

29(e) John etikitie Mwende augire kairitu karugire irio niki? (wh in situ)

John believes Mwende said girl cooked food why.

"Why does John believe mwende said the girl cooked food?"

In conclusion, the wh phrase "niki" for "why" does not behave like all other adjuncts in forming wh questions.

The following is a summary of $w h$-Question formation using the adjuncts:

(i) All the adjuncts allow full wh movement, intermediate wh movement, partial wh movement and wh in situ.

(ii) All moved adjunct wh phrases add the focus marker "ni" except the "why" wh phrase which does notchange its form whether moved or not.

Table 2 shows a summary of all the strategies involved in questioning objects, subjects and adjuncts.

From Table 2, it is evident that objects and adjuncts allow all the strategies of $w h$ question formation except the subjects that do not allow wh in situ.

\subsection{Structural Representation of Objects, Subjects and Adjuncts}

In order to address the second objective which was to describe the structural representations of object, subject and adjunct $w h$ question in Gichuka, the researcher focused formation of $w h$ questions in Gichuka.

Principles and Parameters Theory recognizes that all languages have syntactic phenomena which are handled in structural terms (Chomsky, 1992; Chomsky \& Lasnik, 1993; Culicover, 1997). The theory also states that all languages have a similar syntactic configurations referred to as $\mathrm{x}$-bar schema.

According to the theory, a phrase must contain a maximal projection, a specifier, an intermediate, a head and a complement. The structure of phrases therefore is as shown in Figure 1.

(Culicover, 1997) represents a full structure of any sentence as shown in Figure 2.

\subsubsection{Full $W h$ Movement}

This wh movement involves the wh phrase moving to the specifier of CP of matrix clause. This strategy is allowed when questioning the objects, subjects and adjuncts.

Consider sentence (a):

30(a) Kairitu karugire irio (simple sentence)

Girl cooked food

"The girl cooked food"

(b) Nimbi kairitu karugire? (object wh question)

F-what girl cooked

Table 2. Strategies of $w h$ question formation for objects, subjects and adjuncts, Summary of Strategies of $W h$-question formation in Gichuka.

\begin{tabular}{|c|c|c|c|c|c|}
\hline & & Full $w h$ movement & Partial $w h$ movement & Intermediate $w h$ movement & Wh in situ \\
\hline \multirow{2}{*}{ Objects } & “mbi”(what) & $\sqrt{ }$ & $\sqrt{ }$ & $\sqrt{ }$ & $\sqrt{ }$ \\
\hline & "uu"(who) & $\sqrt{ }$ & $\sqrt{ }$ & $\sqrt{ }$ & $\sqrt{ }$ \\
\hline \multirow[b]{2}{*}{ Subjects } & “mbi”(what) & $\sqrt{ }$ & $\sqrt{ }$ & $\sqrt{ }$ & $\mathrm{x}$ \\
\hline & “uu”(what) & $\sqrt{ }$ & $\sqrt{ }$ & $\sqrt{ }$ & $\mathrm{x}$ \\
\hline \multirow{4}{*}{ Adjuncts } & "ri"(when) & $\sqrt{ }$ & $\sqrt{ }$ & $\sqrt{ }$ & $\sqrt{ }$ \\
\hline & "ku”(where) & $\sqrt{ }$ & $\sqrt{ }$ & $\sqrt{ }$ & $\sqrt{ }$ \\
\hline & “atia”(how) & $\sqrt{ }$ & $\sqrt{ }$ & $\sqrt{ }$ & $\sqrt{ }$ \\
\hline & “niki”(why) & $\sqrt{ }$ & $\sqrt{ }$ & $\sqrt{ }$ & $\sqrt{ }$ \\
\hline
\end{tabular}




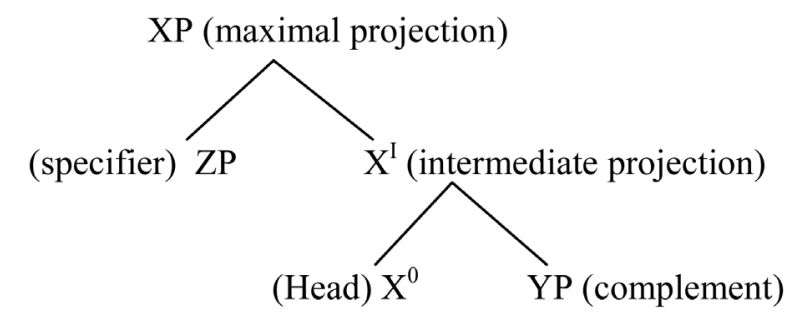

Figure 1. The structure of phrases in X-bar theory.

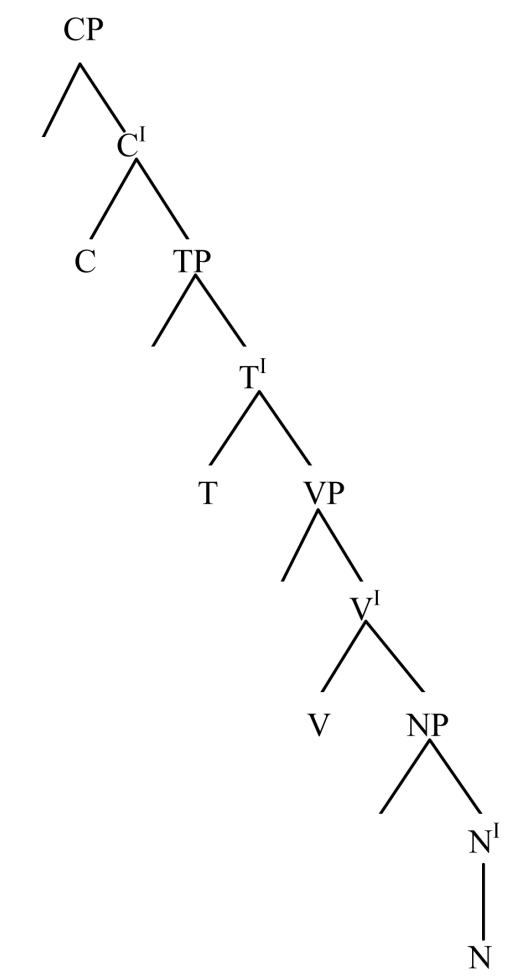

Figure 2. The structure of a sentence.

"What did the girl cook?"

Figure 3 shows the movement of the $w h$ phrase "mbi"to the specifier of $\mathrm{CP}$ of the matrix clause.

In a complex sentence the same distribution is evident as in (31).

(31) Nimbi John etikitie Mwende augire kairitu nikarugire?

f-what John believe Mwende said girl cooked.

"What does John believe Mwende said the girl cooked?"

The structure is shown in Figure 4.

The wh phrase "mbi" moves to the specifier of $\mathrm{CP}$ of matrix clause. The focus marker "ni" is added to it to form the object wh question.

For the subjects, the wh phrase moves from the position of the subject to the specifier of $\mathrm{CP}$ of matrix clause as shown in (32).

(32) Nuu John etikitie Mwende augire niarugire irio?

F-who John believe Mwende said cooked food.

"Who does John believe Mwende said cooked the food?"

The structure is shown in Figure 5.

The adjuncts $w h$ full movement can be represented as in (33)

(33) NIri John etikitie Mwende augire kairitu nikarugire irio? 


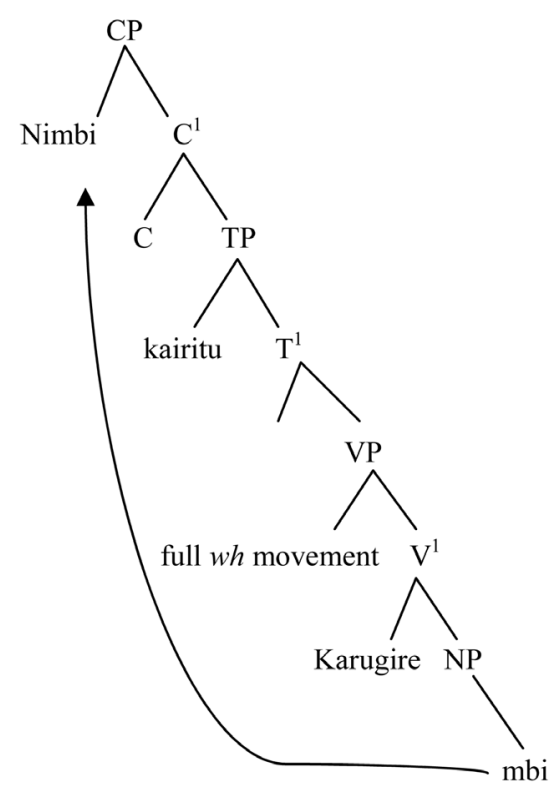

Figure 3. Full wh-movement in Gichuka.

F-when John believe Mwende said girl cooked food.

'When does John believe Mwende said the girl cooked food?'

Figure 6 shows full movement of an adjuncts wh-phrase.

\subsubsection{Partial Wh Movement}

This strategie involves the $w h$ phrase moving to the specifier of $\mathrm{CP}$ of the most embedded clause or the second embedded clause. This strategy is allowed when forming object, subject and adjunct wh question in Gichuka.

In a complex sentence as in (34), the wh phrase moves from the position of the subject to the specifier of CP of the second embedded clause.

(34) John etikitie nuu Mwende augire niarugire irio? (subject wh question)

John believe who Mwende said cooked food?

'Who does Mwende believe cooked food?'

This movement is shown in Figure 7.

This movement can be seen in adjuncts as in (35).

(35) John etikitie nikuMwende augire kairitu nikarugire irio? (adjunct partial wh movement)

John believe f-where Mwende said girl cooked food.

'Where does John believe Mwende said the girl cooked food?'

Adjunct partial wh movement can be shown syntactically as in Figure 8.

\subsubsection{Intermediate Wh Movement}

This strategy involves the movement of the $w h$ phrase to the specifier of $\mathrm{CP}^{\mathrm{I}}$ while the subject is topicalized, and moves to the specifier of topic phrase. Therefore in this strategy, there is topicalization in addition to the $w h$ movement. Consider (36).

(36) John nimbi etikitie Mwende augire kairitu nikarugire? (object wh question)

John f-what believe Mwende said girl cooked.

'What does John believe Mwende said the girl cooked?'

In the example in (36), the wh-phrase 'nimbi' has moved to the specifier of $\mathrm{CP}$, while the subject has been moved to the specifier of Topic phrase as shown in Figure 9.

\subsubsection{Wh in Situ}

This strategy does not allow any movement of the wh phrase. This means that the $w h$ phrase remains in the underlying position of the objects, subjects and adjuncts during the formation of the wh question. However, this 


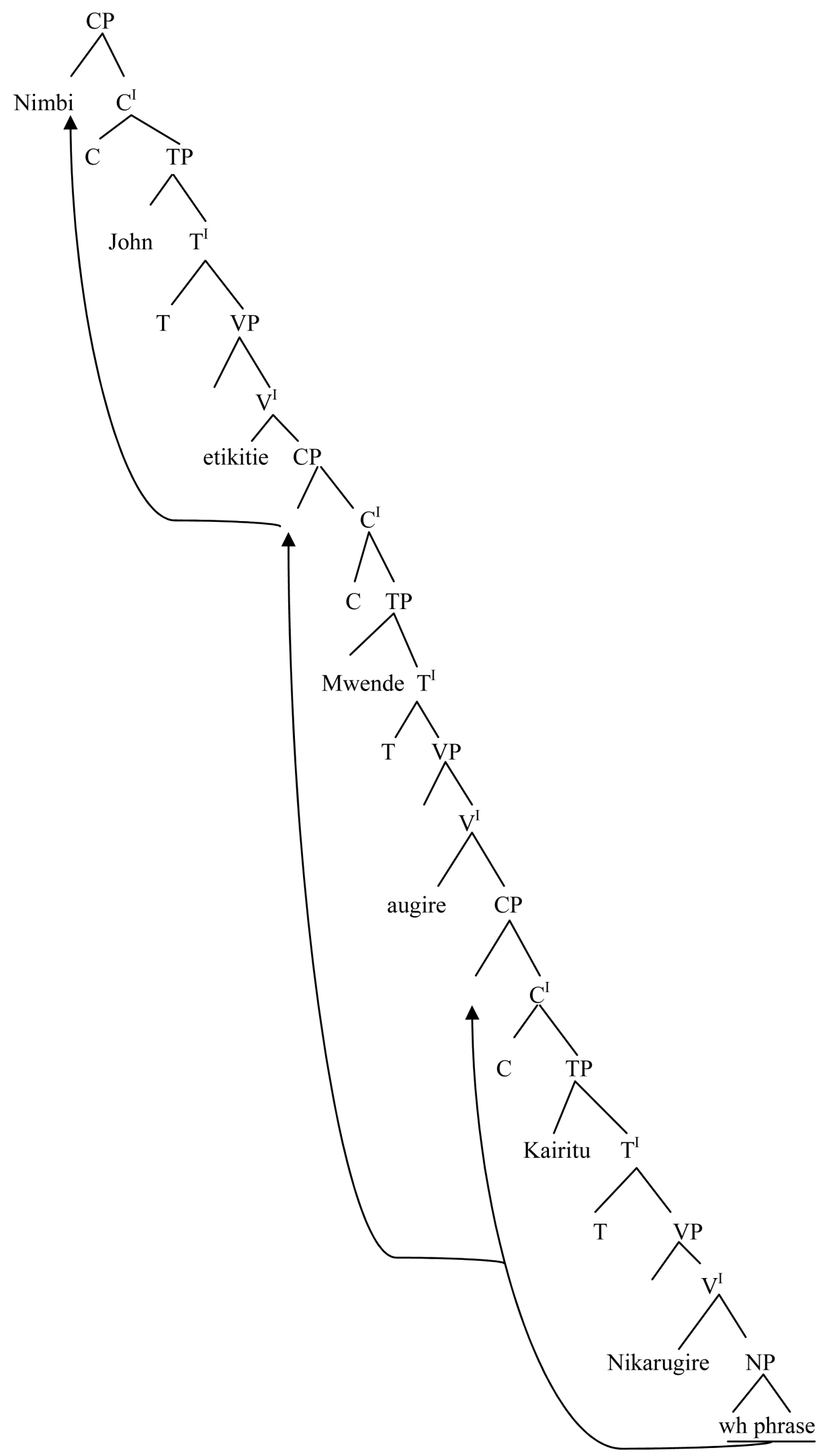




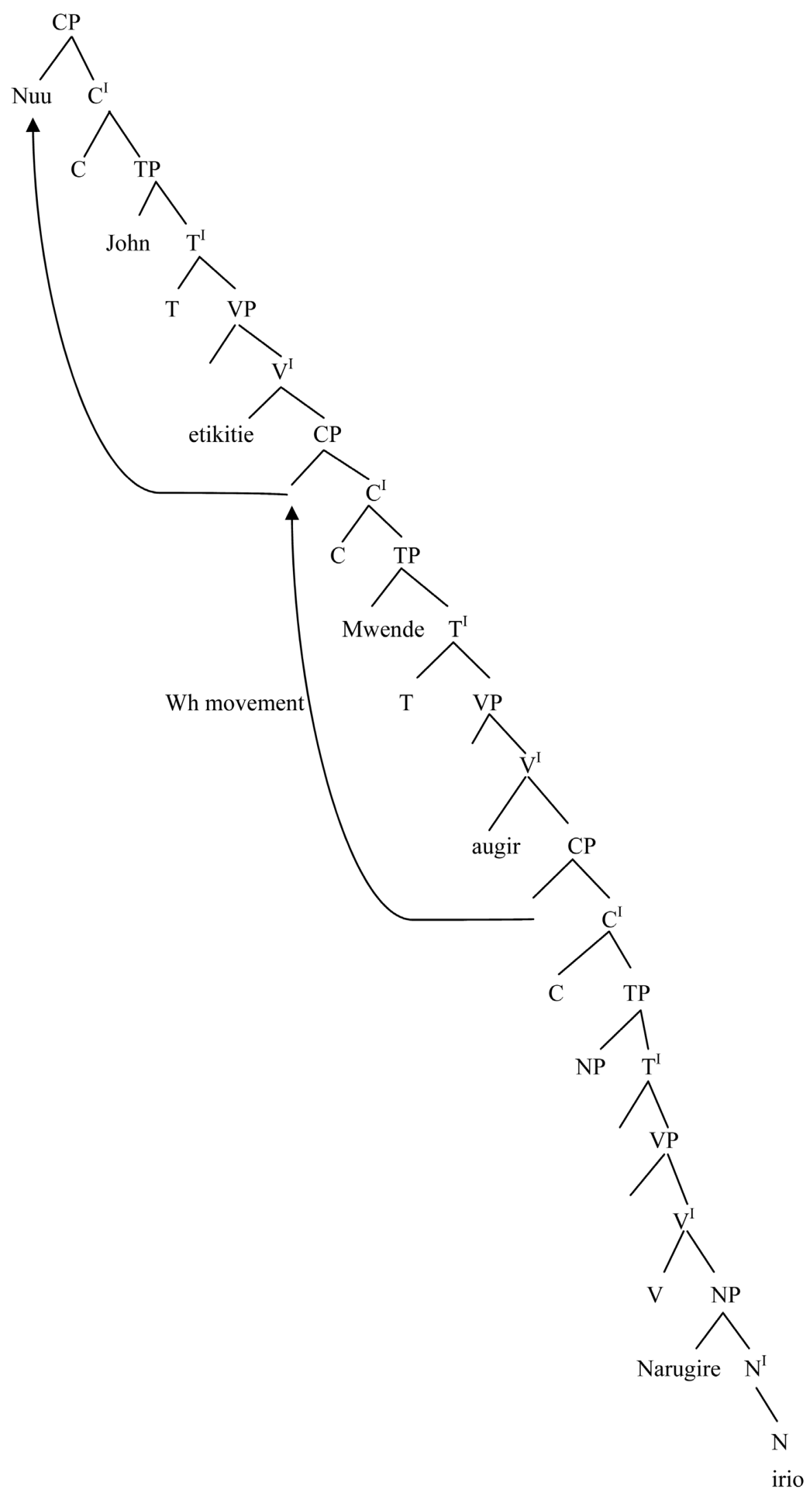

Figure 5. Full wh-movement of a subject in a complex sentence. 


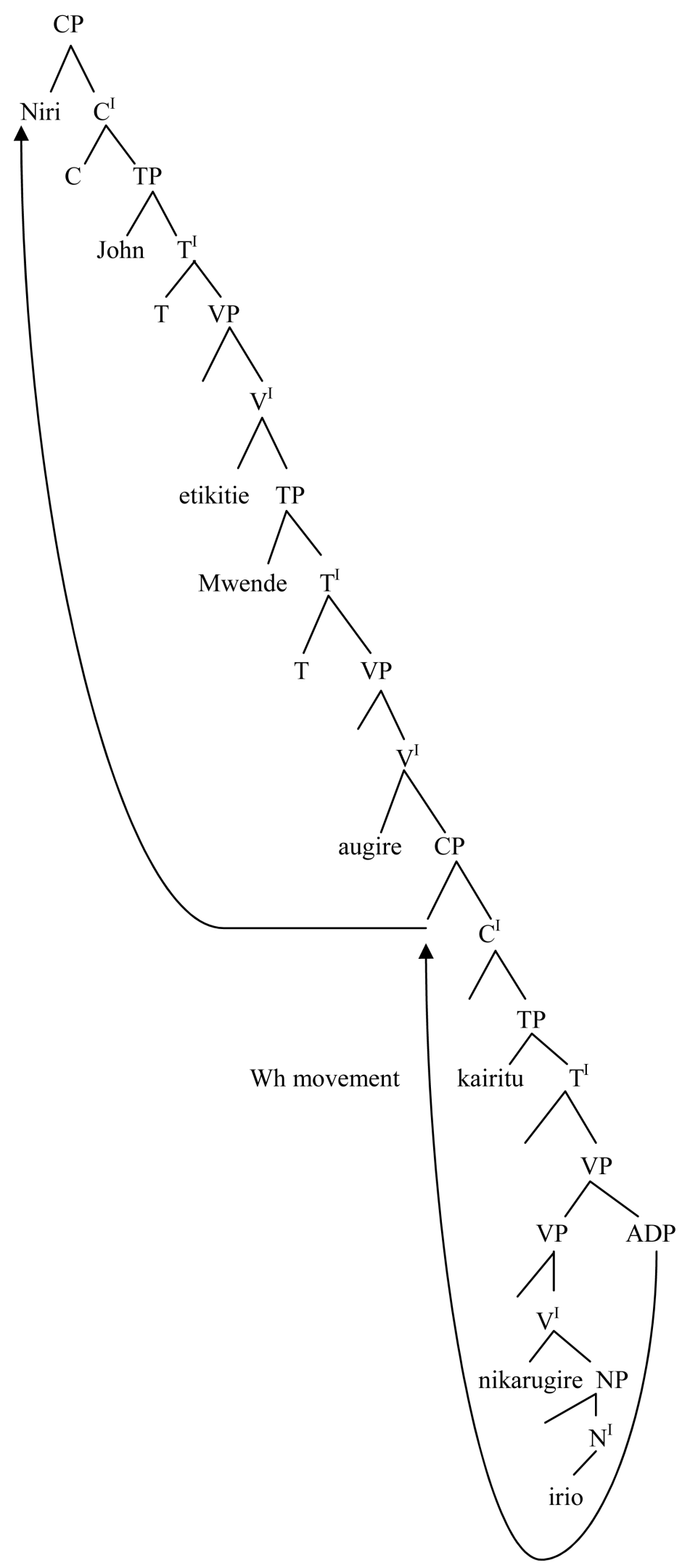

Figure 6. Full wh-movement of an adjunct $w$ h-phrase. 


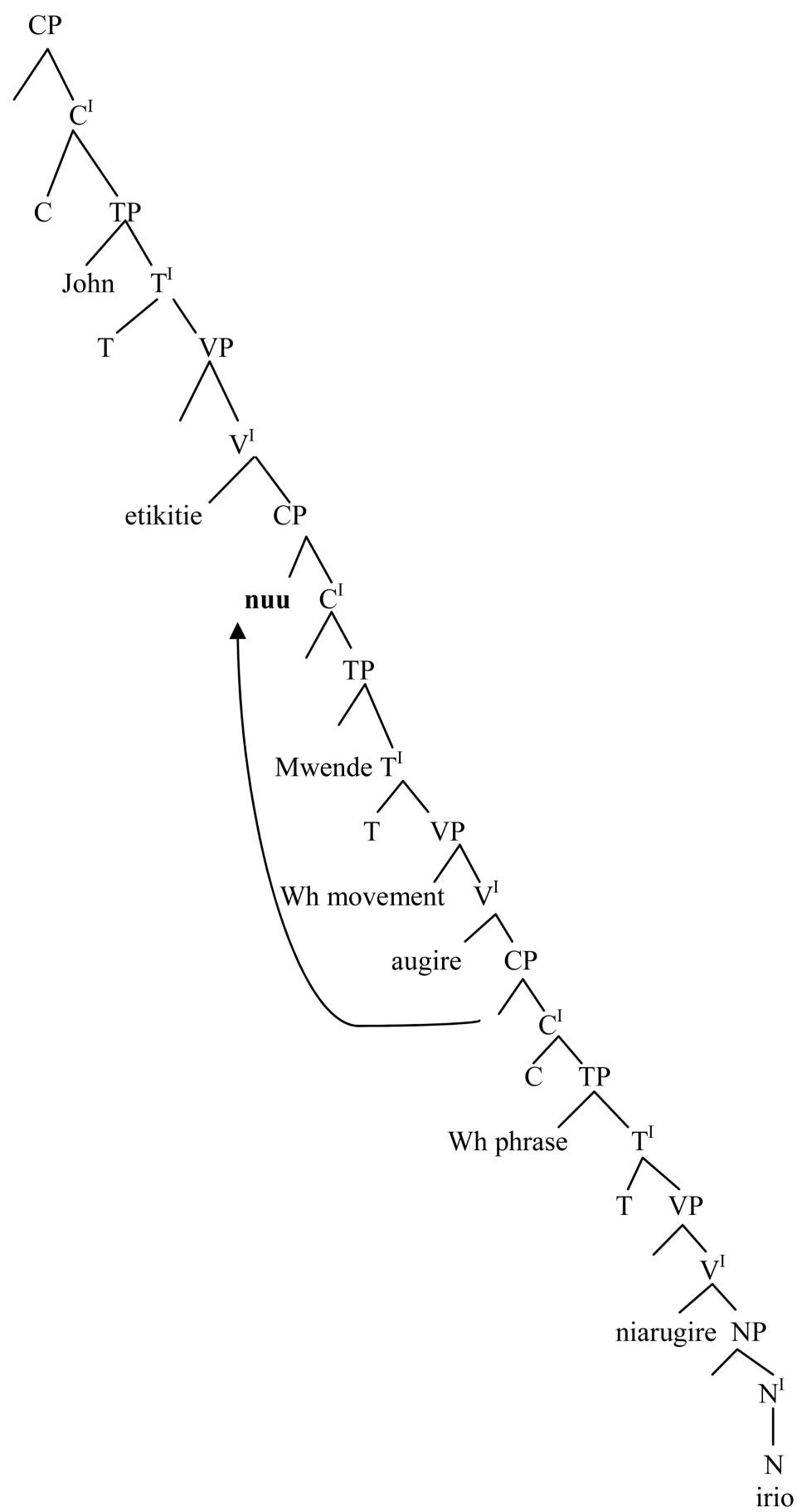

Figure 7. Partial wh-movement of a subject $w$ h-phrase.

strategy is not allowed in subject $w h$ questions as discussed earlier.

In a simple sentence (37), object wh in situ question can be represented as in Figure 10.

(37) Kairitu karugire mbi.

Girl cooked what.

"What did the girl cooked?"

In a complex question (38), it can be represented as Figure 11:

(38) John etikitie Mwende augire kairitu karugire mbi? (object wh question) 


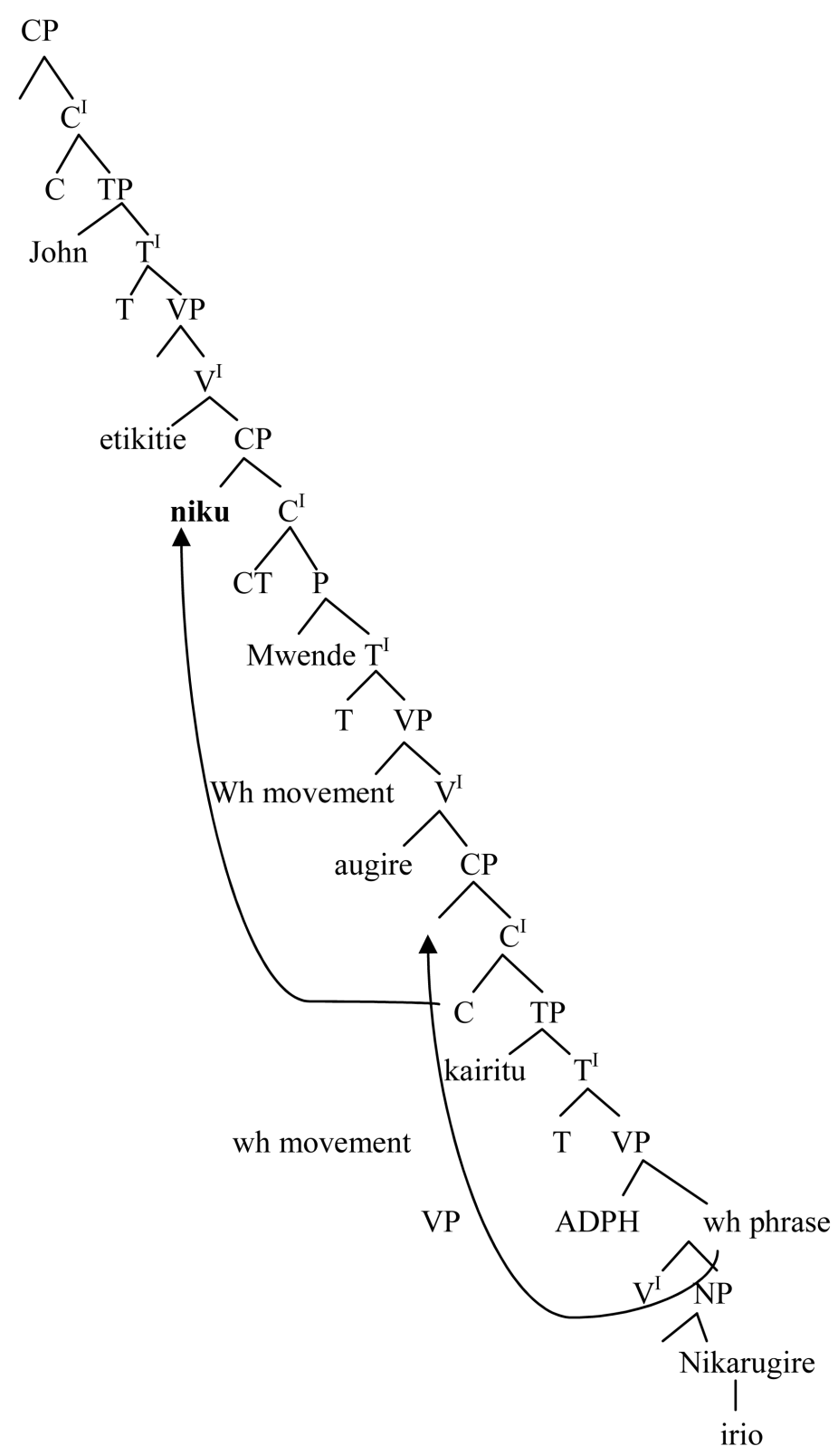

Figure 8. Partial $w h$-movement of an adjunct $w h$-phrase.

John believe Mwende said girl cooked what

"What does Mwende believe the girl cooked?"

The same distribution is shown in adjunct wh in situ. Consider (39).

(39) John etikitie Mwende augire kairitu karugire irio ku?"

John believe Mwende said girl cooked food where.

"Where does John believe Mwende said the girl cooked food?"

The structure is shown in Figure 12.

As shown in Figure 12, the $w h$ phrase is not moving at all, therefore the focus marker is not added.

\section{Conclusion}

(1) Awha phrase in Gichuka can move from its canonical position to a position in the specifier of CP of the matrix clause (full $w h$ movement), it can also land in a position of the specifier of CP of the most embedded or 


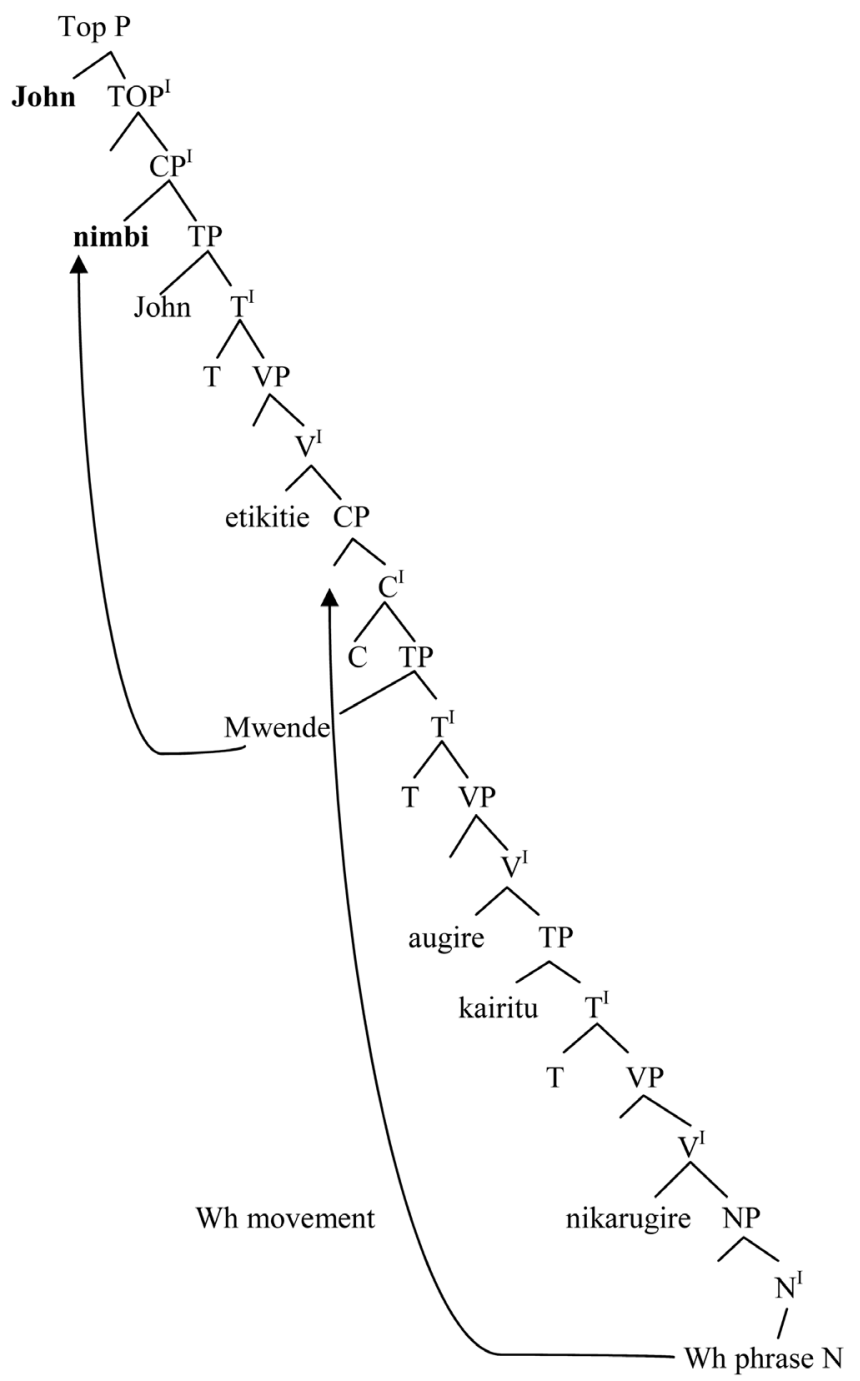

Figure 9. Intermediate $w h$-movement.

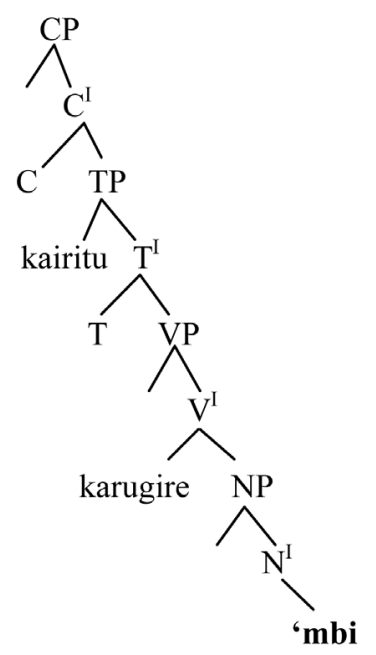

Figure 10. Wh-in situ in a simple sentence. 


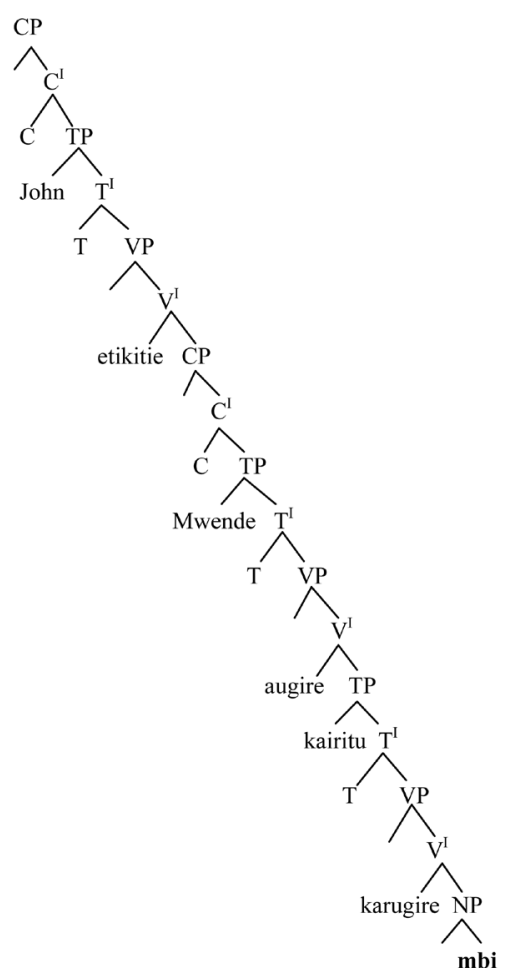

Figure 11. Wh-in situ in a complex sentence.

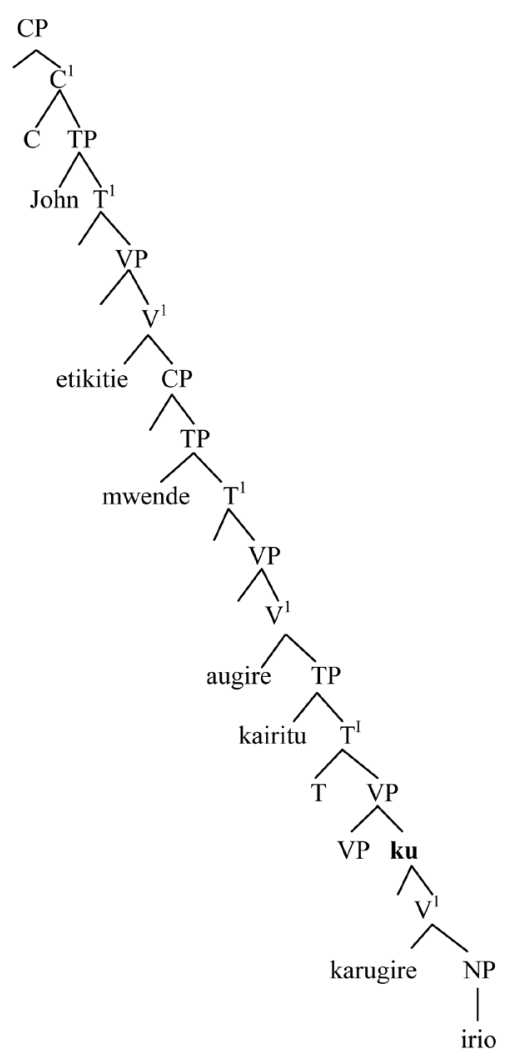

Figure 12. Adjunct wh-in situ in a complex sentence. 
second embedded clause (partial wh movement) and it can remain in the underlying position of objects and adjuncts (wh in situ).

(2) Wh in situ is not allowed in forming subject wh questions.

(3) Intermediate $w h$ movement is also evident in Gichuka where the $w h$ phrase moves to the specifier of $\mathrm{CP}^{\mathrm{I}}$ while the topicalized constituent (subject) moves to the specifier of Top.

\section{References}

Anisa, S. (2009). Wh-questions in Dholuo. http://people.umass.edu

Bergvall, V. (1987). Focus in Kikuyu and Universal Grammar. Ph.D. Dissertation. Cambridge: Havard University.

Clements, G. N., \& Kevin, C. F. (1979). Kikuyu Tone Shift and Its Synchronic Consequences. Linguistic Inquiry, 10, 179210.

Chomsky, N. (1977). On Wh-Movement. In P. Cullicover, T. Wasow, \& A. Akmajian (Eds.), Formal Syntax (pp. 71-132). New York: Academic Press.

Clements, G. N. (1984). Biding Domains in Kikuyu. Studies in the Linguistics Science, 14, 37-56.

Culicover, P. (1997). Principles and Parameters Theory: An Introduction to Syntactic Theory. New York: Oxford University Press.

Fromkin, V., Robert, R., Neil, H., \& Harry, L. (2001). An Introduction to Language. Scarborough: Thomas, Nelson.

Kristin, D. (2000). Optional Wh-Movment in Babine-Witsuwiten. Dordrecht: Kluwer Academic Publishers.

McDaniel, D. (1986). Conditions on Wh-Chins. Doctoral Dissertation, New York: City University of New York, Cuny publishers.

Muriungi, P. (2003). Wh-Questions in Kitharaka. Unpublished MA Thesis, Johannesburg: The University of the Witwatersrand.

Puskas, G. (1997). Focus and CP Domain. In L. Haegeman (Ed.), The New Comparative Syntax (pp. 33-63). New York: Addisson Wessley Longman.

Norberto (2004). Wh-Movement.

Sabel, J., \& Jochem, Z. (2004). Wh-Question Formation in Nguni. In J. Mugane, J. P. Hutchinson, \& D. A. Worman (Eds.), African Languages and Linguistics. 